\title{
Effects of Temperature on the Characteristics of Nitrogen Removal and Microbial Community in Post Solid-Phase Denitrification Biofilter Process
}

\author{
Qian Zhang ${ }^{1}$, Xue Chen ${ }^{1}$, Wandong Luo ${ }^{1}$, Heng Wu ${ }^{1}$, Xiangyang Liu ${ }^{1}$, Wang Chen ${ }^{1}$, \\ Jianhong Tang ${ }^{1}$ and Lijie Zhang ${ }^{2, *}$ \\ 1 School of Chemistry and Chemical Engineering, Chongqing University of Technology, \\ Chongqing 400054, China; zhangqianswu2005@163.com (Q.Z.); 15823108783@163.com (X.C.); \\ lwd265588@163.com (W.L.); wuhengdyx@163.com (H.W.); liuxy@2017.cqut.edu.cn (X.L.); \\ 18323050874@163.com (W.C.); nidhogg_t@163.com (J.T.) \\ 2 School of Pharmacy and Bioengineering, Chongqing University of Technology, Chongqing 400054, China \\ * Correspondence: zhljtt@cqut.edu.cn; Tel.: +86-177-2519-9400
}

Received: 25 September 2019; Accepted: 4 November 2019; Published: 13 November 2019

\begin{abstract}
In order to solve the problems of high energy consumption, complex process and low nitrogen removal efficiency in the currently available low carbon source wastewater treatment processes, a novel coagulation sedimentation/post-solid-phase denitrification biofilter process (CS-BAF-SPDB) was proposed. The effect of temperature on the nitrogen removal performance of BAF-SPDB was intensively studied, and the mechanism of the effect of temperature on nitrogen removal performance was analyzed from the perspective of microbial community structure by using the polymerase chain reaction denaturing gradient gel electrophoresis (PCR-DGGE). The results showed that, to realize favorable nitrifying and denitrifying performance simultaneously in the BAF-SPDB unit, the operation temperature should be set above $18^{\circ} \mathrm{C}$. In addition, the influence of the macro operation parameters on the performance of the BAF and SPDB has a direct relationship with the dynamic changes of the micro microbial community. The influence of temperature on nitrification performance in BAF was mainly embodied in the change of composition, amount and activity of ammonia oxidizing bacteria Candidatus Nitrospira defluvii and nitrite oxidizing bacteria Nitrosomonas sp. Nm47, while that on denitrification performance in SPDB is mainly embodied in the change of composition and amount of solid carbon substrate degrading denitrifying bacteria Pseudomonas sp., Myxobacterium AT3-03 and heterotrophic denitrifying bacteria Dechloromonas agitate, Thauera aminoaromatica, Comamonas granuli and Rubrivivax gelatinosus.
\end{abstract}

Keywords: biodegradable polymers; gas/water ratio; microbial community; PCR-DGGE; post solid-phase denitrification

\section{Introduction}

In recent years, municipal domestic wastewater has become characterized by a low carbon to nitrogen $(\mathrm{C} / \mathrm{N})$ ratio [1]. Several treatment ways of nitrogen have been established, such as physical/chemical method, which normally require high operational cost, low selectivity, and produce brine wastes [2]. Sulfur-based autotrophic denitrification processes were also a method of nitrogen removal, but as Hao et al. and Qiu et al. reported, it has a complicated sulfur oxidation process which is difficult to control [3,4], presenting serious problems for nitrogen removal from wastewater, e.g., high operation costs caused by excessive external carbon source dosage and high recycle ratio, sludge bulking under low organic loading and low dissolved oxygen and poor nitrogen removal efficiency [5-7]. 
In this study, we propose a novel post denitrification strategy based on solid-phase denitrification to realize high nitrogen removal efficiency from wastewater with a low $\mathrm{C} / \mathrm{N}$ ratio. This strategy is termed coagulation sedimentation-post solid-phase denitrification biofilter process (CS-BAF-SPDB). In the first step, most of the suspended solids and organic matter are removed in the coagulation sedimentation unit (CS), which could not only ease the blockage of the subsequent biological filters unit, but also to avoid the impact of organic matter on the nitrification. In the second step, ammonia nitrogen is oxidized to nitrate nitrogen in the biological aeration filter (BAF). Compared with the activated sludge process, the advantage of BAF is that the biomass of nitrifying microorganism is guaranteed, and sludge bulking would not occur even under low organic carbon loading and low dissolved oxygen. The effluent of BAF then flows into the solid-phase denitrification biofilter (SPDB), and the nitrate nitrogen in the effluent is converted to $\mathrm{N}_{2}$. Considering the biodegradability, the start-up cycle and the stability of the degradation process, we have chosen the biodegradable polymer polycaprolactone (PCL) instead of other biodegradable polymers in SPDB [8-12], as PCL is used as both a biofilm support and a carbon source. Denitrifying bacteria in the biofilm coating onto the surface of the PCL carrier could degrade PCL to acquire the necessary electron donor for denitrification. In addition, the organic carbon released from PCL could also eliminate the dissolved oxygen in the influent to maintain the anoxic environment. Previous studies have also shown that the solid carbon source has a high mechanical strength and a very long service life (mass loss of $0.03 \%$ per day), so that a long-term stable denitrification performance can be maintained in SPDB [13]. In previous research, using various biodegradable polymers (e.g., PHB, PCL, PLA and polymer blends) as both a carbon source and biofilm support for treating nitrate contaminated water in a single reactor (e.g., packed-bed and moving bed biofilm reactor, constructed wetland, etc.) has been widely studied [8-12]. However, research on using the combination process of SPDB and BAF for low carbon domestic wastewater treatment has rarely been reported.

Temperature is one of the key factors affecting nitrogen removal efficiency of BAF-SPDB process $[14,15]$. It not only affects the activity, specific growth rate and community structure of nitrifying and denitrifying microorganisms, but also has a certain impact on the concentration of dissolved oxygen, and thereby has an impact on nitrification and denitrification. Therefore, to determine the appropriate operating temperature is the key to ensure the ideal nitrogen removal efficiency of this process. However, the effect of temperature on the combination process of SPDB and BAF for low carbon wastewater treatment has rarely been reported. In addition, little information is available on the functional bacteria predominating in this nitrogen removal process and the change of microbial community structure in BAF and SPDB with changing temperature, so further research is necessary.

The start-up of this novel process and the effect of influent carbon/nitrogen ratio, gas/water ratio, hydraulic detention time and influent ammonia loading on the nitrogen removal efficiency of BAF-SPDB was investigated in the preliminary study in our laboratory [16]. On this basis, this paper focuses on the influence of temperature on process' nitrogen removal efficiency, and the changes of microbial community structure with temperature are studied by using a polymerase chain reaction-denaturing gradient gel electrophoresis (PCR-DGGE) technique to provide the microbiological basis for the research of process optimization and nitrogen removal mechanism.

\section{Materials and Methods}

\subsection{Materials}

Polycaprolactone (PCL) and clay ceramsite carriers were kindly supplied by Shenzhen Esun Industrial Co. Ltd and Jiangxi Pingxiang Sanhe Ceramics Co., Ltd. Their physical-chemical properties are shown in Table 1. 
Table 1. Physical-chemical properties of the two biofilm carriers used in the experiment. Polycaprolactone, PCL.

\begin{tabular}{ccccccc}
\hline Carrier Type & $\begin{array}{c}\text { Product } \\
\text { Mark }\end{array}$ & $\begin{array}{c}\text { Appearance } \\
\text { Shape }\end{array}$ & $\begin{array}{c}\text { Density } \\
(\mathbf{g} / \mathbf{m L})\end{array}$ & $\begin{array}{c}\text { Diameter } \\
(\mathbf{m m})\end{array}$ & $\begin{array}{c}\text { Height } \\
(\mathbf{m m})\end{array}$ & $\begin{array}{c}\text { Molecular } \\
\text { Weight (Dalton) }\end{array}$ \\
\hline $\begin{array}{c}\text { Clay } \\
\begin{array}{c}\text { Ceramsite } \\
\text { PCL }\end{array}\end{array}$ & PP-B 3.0 & pellet & 1.67 & $4-6$ & - & - \\
\hline
\end{tabular}

Domestic wastewater from student dormitories of Chongqing University, China (29.611011N, 106.299419E) was used as feed water. The water quality parameters of the influent were as follows: $\varrho\left(\mathrm{COD}_{\mathrm{Cr}}\right)=148-185 \mathrm{mg} / \mathrm{L}, \varrho\left(\mathrm{NH}_{4}{ }^{+}-\mathrm{N}\right)=26.7-56.8 \mathrm{mg} / \mathrm{L}, \varrho(\mathrm{TN})=28.6-70.2 \mathrm{mg} / \mathrm{L}, \varrho(\mathrm{SS})$ $=140.0-152.5 \mathrm{mg} / \mathrm{L}$. To investigate the effect of operation conditions on nitrogen removal efficiency of the process, $\mathrm{COD}_{\mathrm{Cr}}, \mathrm{NH}_{4}{ }^{+}-\mathrm{N}$ and $\mathrm{PO}_{4}{ }^{-}-\mathrm{P}$ concentration in the feed water were controlled by dilution or adding sodium acetate ammonium chloride and potassium dihydrogen phosphate to maintain the stability of water quality.

Activated sludge, obtained from the aerobic and anaerobic tank of $\mathrm{A}^{2} / \mathrm{O}$ process in Yongchuan Sewage Plant, Chongqing, China (29.397933N, 105.965335E), was used as seed source for BAF and $\mathrm{SPDB}$, and the concentration of the activated sludge was $4.2 \mathrm{~g} / \mathrm{L}$ and $5.6 \mathrm{~g} / \mathrm{L}$, respectively.

\subsection{Experimental Apparatus}

Figure 1 illustrates the schematic diagram of the CS-BAF-SPDB process, which combined the coagulation sedimentation unit with the biofilter system. The volume of both the coagulation and sedimentation tank was $5 \mathrm{~L}$, and a sampling point $(\mathrm{C})$ was set up in the effluent of the sedimentation tank. The biofilter system consisted of two cylindrical columns. The first column, which was aerated for nitrification, was $175 \mathrm{~cm}$ in height and had an inner diameter of $8 \mathrm{~cm}$. This column was packed with ceramic balls of $0.4-0.6 \mathrm{~cm}$ in diameter, and the packing height was $87 \mathrm{~cm}$. Four sampling points (B1, B2, B3 and B4) were set up from the bottom to the top along the BAF. The second column was in $130 \mathrm{~cm}$ height and has an inner diameter of $8 \mathrm{~cm}$. This column is packed with PCL particles as biofilm support and electron donor, and the packing height was $27 \mathrm{~cm}$. Three sampling points (D1, D2 and D3) were set up along the SPBD. The effective volume (liquid volume) of each column was 4.0 and $3.2 \mathrm{~L}$, respectively. The flow rate of the influent was controlled by peristaltic pumps (Longer BT100-2J, China). The aeration rate of the BAF was controlled by gas flow meter (Senlod LZB-3, China). The water temperature was strictly controlled by electrical heating tape wrapped around the biofilter reactors. 


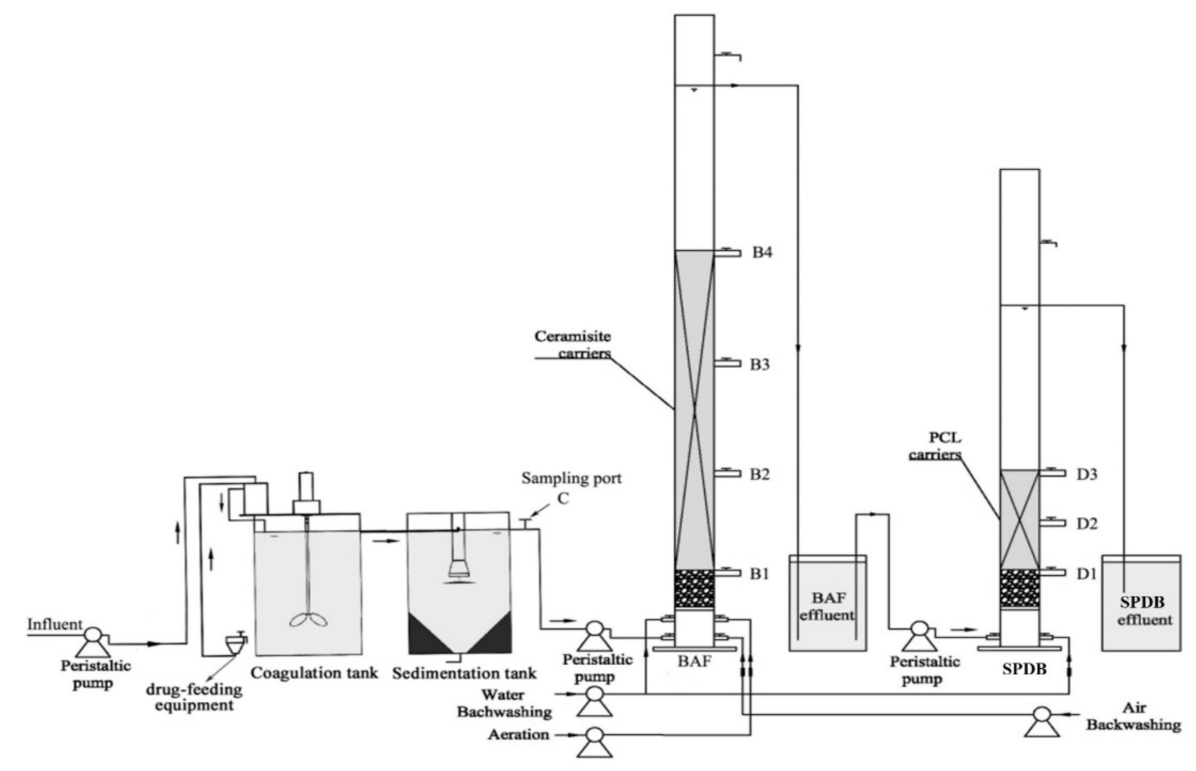

Figure 1. Schematic diagram of the sedimentation/post-solid-phase denitrification biofilter (CS-P-SPDB) process cascade.

\subsection{Experimental Procedure and Sampling Methods}

The start-up of the CS-BAF-SPDB process was successfully achieved in the previous study [16], and the optimum operating condition, such as influent $\mathrm{C} / \mathrm{N}$ ratio and gas/water ratio of $\mathrm{BAF}$, the hydraulic retention time (HRT) of BAF and SPDB, were also determined. In order to study the influence of changing temperature on the nitrogen removal performance of CS-BAF-SPDB process under low carbon conditions, influent ammonia concentration was kept at $30 \mathrm{mg} / \mathrm{L}, \mathrm{C} / \mathrm{N}$ ratio in the effluent of CS units was maintained at 3:1, gas/water ratio of BAF was set at 4:1, the HRT of BAF and SPDB was control at $4 \mathrm{~h}$ and $2 \mathrm{~h}$, respectively, and the temperature was changed between 32 and $13{ }^{\circ} \mathrm{C}$. Sampling at a fixed time each day, once the effluent ammonia, nitrate and TN concentration from three continuous daily tests were within $5 \%$ of each other, the reactor was assumed to be operated at steady state condition under a certain temperature and the temperature was then changed into another level. In a previous study, it was confirmed that the nitrifying bacteria predominated in the B3 sampling point of BAF, and denitrifying bacteria mainly predominated in D2 sampling point of SPDB [16]. Therefore, biofilm samples from B3 and D2 were more representative. When the process operated at steady state condition under each temperature, ceramsite and PCL carriers with biofilm coating onto the surface were taken from B3 and D2 sampling points, respectively. Biofilms were removed by ultrasonic device, and the samples were preserved at $-20^{\circ} \mathrm{C}$ for further analysis. The morphology of the solid samples was observed using an environmental scanning electron microscope (ESEM) (Quanta 200 FEG, Hillsboro, OR, USA).

\subsection{Extraction of Sample Genomic DNA}

Genomic DNA samples were extracted by using rapid extraction kit of silt genomic DNA (Baisaike, Cat\#DP4011, Beijing, China).

\subsection{PCR Amplification of $16 S$ rDNA Fragments in Bacterial}

Taking sample genomic DNA as templates, hypervariable region sequences of samples of $16 \mathrm{~S}$ rDNA were amplified using two universal primers: GC-338F and 518R bacterial.

System for PCR amplification ( $50 \mu \mathrm{L}): 10 \times$ PCR buffer $5 \mu \mathrm{L}$, dNTP $(2.5 \mathrm{mM}) 3.2 \mu \mathrm{L}$, rTaq $(5 \mathrm{U} / \mu \mathrm{L})$ $0.4 \mu \mathrm{L}, \mathrm{GC}-338 \mathrm{~F} 20 \mu \mathrm{M} 1 \mu \mathrm{L}, 518 \mathrm{R}(20 \mu \mathrm{M}) 1 \mu \mathrm{L}$, template DNA $50 \mathrm{ng}$, adding ddH2O to $50 \mu \mathrm{L}$. 
Program PCR amplification: pre-denaturation at $94{ }^{\circ} \mathrm{C}$ for $5 \mathrm{~min}$, denaturation at $94^{\circ} \mathrm{C}$ for $1 \mathrm{~min}$, annealing at $55^{\circ} \mathrm{C}$ for $45 \mathrm{~s}$, extension at $72{ }^{\circ} \mathrm{C}$ for $1 \mathrm{~min}, 30$ cycles, and final extension at $72{ }^{\circ} \mathrm{C}$ for $10 \mathrm{~min}$.

PCR products were purified and recycled using DNA Gel Extraction Kit of OMEGA.

PCR Instrument was T-gradient produced by Biometra, Gel Imager was Gel-Doc2000 produced by Bio-Rad. The universal primer information is shown in Table 2.

Table 2. Universal Primer information.

\begin{tabular}{cc}
\hline Primer & Sequence \\
\hline $338 \mathrm{~F}$ & CCT ACG GGA GGC AGC AG \\
$518 \mathrm{R}$ & ATT ACC GCG GCT GCT GG \\
& CC338F \\
& CCT ACG GGA GGC AGC AG \\
\hline
\end{tabular}

\subsection{Analysis of the PCR Products by Denaturing Gradient Gel Electrophoresis (DGGE)}

$10 \mu \mathrm{L}$ PCR products were taken for DGGE analysis. Electrophoresis was proceeded at $150 \mathrm{~V}, 60^{\circ} \mathrm{C}$, in $1 \times$ TAE buffer for 5 hours with a denatured gradient from $35 \%$ to $55 \%$, and $8 \%$ polyacrylamide gel. The chemical denaturing agent was $100 \%$ urea $7 \mathrm{~mol} / \mathrm{L}$, along with $40 \%$ acrylamide(v/v). The level of DGGE gel formulations (Table 3) were among $35 \%-55 \%$ of denatured gradient.

Table 3. Denaturing Gradient Gel Electrophoresis (DGGE) gel formulations.

\begin{tabular}{ccc}
\hline Reagent & $\mathbf{3 5 \%}$ & $\mathbf{5 5 \%}$ \\
\hline 30\% Acrylamide/Bis & $4 \mathrm{~mL}$ & $4 \mathrm{~mL}$ \\
$50 \times$ TAE buffer & $0.3 \mathrm{~mL}$ & $0.3 \mathrm{~mL}$ \\
Formamide (deionized) & $2.1 \mathrm{~mL}$ & $3.3 \mathrm{~mL}$ \\
Urea & $2.205 \mathrm{~g}$ & $3.465 \mathrm{~g}$ \\
dH2O & To $15 \mathrm{~mL}$ & To $15 \mathrm{~mL}$ \\
APS & $120 \mu \mathrm{L}$ & $120 \mu \mathrm{L}$ \\
TEMED & $10 \mu \mathrm{L}$ & $10 \mu \mathrm{L}$ \\
\hline
\end{tabular}

After denaturing gradient gel electrophoresis (DGGE), the steps of silver staining were interpreted as follows:

1. Fixed for $15 \mathrm{~min}$ with fixative (a constant volume of $500 \mathrm{~mL}$ with $50 \mathrm{mLC}_{2} \mathrm{H}_{5} \mathrm{OH}$ and $2.5 \mathrm{~mL}$ $\left.\mathrm{CH}_{3} \mathrm{COOH}\right)$.

2. Cleaned with Milli-Q pure water, $20 \mathrm{~s}$ and 2 min each time.

3. Stained for $15 \mathrm{~min}$ with silver dye (a constant volume of $500 \mathrm{~mL}$ with $1 \mathrm{~g} \mathrm{AgNO}_{3}$ and $0.75 \mathrm{~mL}$ $37 \% \mathrm{HCHO}$ ).

4. Cleaned with Milli-Q pure water for $20 \mathrm{~s}$ and 2 min each time.

5. Colored for 5-7 min with color solution (a constant volume of $500 \mathrm{~mL}$ with $7.5 \mathrm{~g} \mathrm{NaOH}$ and $2.5 \mathrm{~mL} \mathrm{37 \%} \mathrm{HCHO}$ ).

6. Finally, the reaction was terminated with stop solution (a constant volume of $500 \mathrm{~mL}$ with $50 \mathrm{~mL}$ $\mathrm{C}_{2} \mathrm{H}_{5} \mathrm{OH}$ and $\left.2.5 \mathrm{~mL} \mathrm{CH}_{3} \mathrm{COOH}\right)$.

\subsection{Recycling and Sequencing of the Dominant Bands in the DGGE Profiles}

DGGE strips were cut and recovered with sterilized scalpel, and recycled target band using Poly-Gel DNA Extraction Kit of OMEGA. $2 \mu \mathrm{L}$ recovered products were used as template, using $338 \mathrm{~F} / 518 \mathrm{R}$ as primers to $\mathrm{PCR}$ reactions.

PCR amplification system $(50 \mu \mathrm{L}): 10 \times$ PCR buffer $5 \mu \mathrm{L}$, dNTP $(2.5 \mathrm{mM}) 3.2 \mu \mathrm{L}, \mathrm{rTaq}(5 \mathrm{U} / \mu \mathrm{L})$ $0.4 \mu \mathrm{L}, 338 \mathrm{~F}(20 \mathrm{mM}) 1 \mu \mathrm{L}, 518 \mathrm{R}(20 \mathrm{mM}) 1 \mu \mathrm{L}$, template DNA $1 \mu \mathrm{L}$, adding $\mathrm{ddH}_{2} \mathrm{O}$ to $50 \mu \mathrm{L}$. 
PCR amplification program: pre-denaturation at $94{ }^{\circ} \mathrm{C}$ for $4 \mathrm{~min}$, denaturation at $94{ }^{\circ} \mathrm{C}$ for $30 \mathrm{~s}$, annealing at $55^{\circ} \mathrm{C}$ for $30 \mathrm{~s}$, extension at $72{ }^{\circ} \mathrm{C}$ for $30 \mathrm{~s}, 30$ cycles, and final extension at $72{ }^{\circ} \mathrm{C}$ for $10 \mathrm{~min}$.

The re-amplified DNA fragments were recovered, purified and connected to the carrierpMD18vectors. Then they were transformed into $\mathrm{DH} 5 \alpha$ competent cells, and positive clones were screened. Finally, bacterial 16S rDNA fragments inserted in broth were sequenced by BGI.

\subsection{Data Analysis}

The dominant DGGE bands in the lane of BAF and SPDB, which changed obviously during the temperature changing process, were successfully re-amplified, cloned, sequenced and aligned with BLAST to get access to the $16 \mathrm{~S}$ rDNA sequence of the most similar to type strain with BLAST program for homology in GenBank. Phylogenetic tree was constructed with the neighbor-joining method by employing MEGA5 software, bootstrap index was 1000.

\section{Results and Discussion}

\subsection{The Influence of Temperature on Nitrogen Removal Efficiency of CS-BAF-SPDB}

As can be seen from Figure 2a, when the temperature is above $18{ }^{\circ} \mathrm{C}$, changing temperature had little effect on nitrification activities, and $\mathrm{NO}_{3}{ }^{-} \mathrm{N}$ in the effluent of BAF showed almost no change. However, nitrification in $\mathrm{BAF}$ was obviously inhibited with the temperature decreasing from $18{ }^{\circ} \mathrm{C}$ to $13{ }^{\circ} \mathrm{C}$, and $\mathrm{NH}_{4}{ }^{+}-\mathrm{N}$ removal efficiency decreased from $98.0 \%$ at $18{ }^{\circ} \mathrm{C}$ to $78.1 \%$ at $13{ }^{\circ} \mathrm{C}$ (Figure $2 \mathrm{~b}$ ). This was consistent with the previous studies that $\mathrm{NH}_{4}{ }^{+}-\mathrm{N}$ removal efficiency decreased from 85.7-96.3\% at a water temperature of $20-25^{\circ} \mathrm{C}$ to $71.9-87.8 \%$ at $7-10^{\circ} \mathrm{C}$ in a BAF packed with zeolite as biofilm support [17]. Antoniou et al. [18] pointed out that the effective maximum specific growth rate of nitrifying bacteria was found to be a monotonically increasing function of temperature in the range of $15-25^{\circ} \mathrm{C}$. Therefore, the decrease of temperature might affect the maximum specific growth rate of the nitrifying bacteria, and further influence the nitrification process. Similarly, when the temperature was above $26{ }^{\circ} \mathrm{C}$, temperature changing has little effect on denitrification in the SPDB. When the temperature further decreased, however, denitrification in SPDB was obviously inhibited, and $\mathrm{NO}_{3}{ }^{-} \mathrm{N}$ in the effluent of SPDB gradually increased from $0.1 \mathrm{mg} / \mathrm{L}$ at $26{ }^{\circ} \mathrm{C}$ to $8.8 \mathrm{mg} / \mathrm{L}$ at $13^{\circ} \mathrm{C}$ (Figure 2a). Wang and Wang [19] also found that the nitrate removal efficiency decreased from nearly $100 \%$ at 25 ${ }^{\circ} \mathrm{C}$ to $50 \%$ at $12{ }^{\circ} \mathrm{C}$ with a HRT of $2 \mathrm{~h}$ when using biodegradable snack ware (BSM) as carbon source for denitrification. Rusmana et al. [20] found that the maximum specific growth rate of denitrifying bacteria increased with the increase of temperature, and reached its maximum when the temperature was $26^{\circ} \mathrm{C}$, which explained the little effect of changing temperature on denitrification performance when the temperature increase from $26^{\circ} \mathrm{C}$ to $32{ }^{\circ} \mathrm{C}$. In addition, the decrease in temperature leads to the increase of the DO concentration in the effluent of nitrifying biofilter, which might be another reason for the worse denitrification performance under low temperature. Therefore, the temperature of the novel process should be kept above $18{ }^{\circ} \mathrm{C}$ to obtain high nitrification and denitrification performance simultaneously. From Figure 2c, it can also be seen that when the temperature decreased from 20 to 13 ${ }^{\circ} \mathrm{C}$, nitrite accumulation was observed obviously in the effluent of BAF, but the nitrite concentration in the effluent of SPDB was maintained at a very low level during the whole process. From Figure 2d, it can also be seen that when the temperature decreased from 32 to $13{ }^{\circ} \mathrm{C}$, TN removal efficiency was $15.6 \%$ which was relatively stable in the effluent of BAF. However, the TN concentration in the effluent of SPDB was maintained at a very low level at $32{ }^{\circ} \mathrm{C}$ and $26^{\circ} \mathrm{C}$, and TN removal efficiency was $87.9 \%$. When temperature decreased from 20 to $13^{\circ} \mathrm{C}$, $\mathrm{TN}$ accumulation was observed obviously in the effluent of SPDB. 

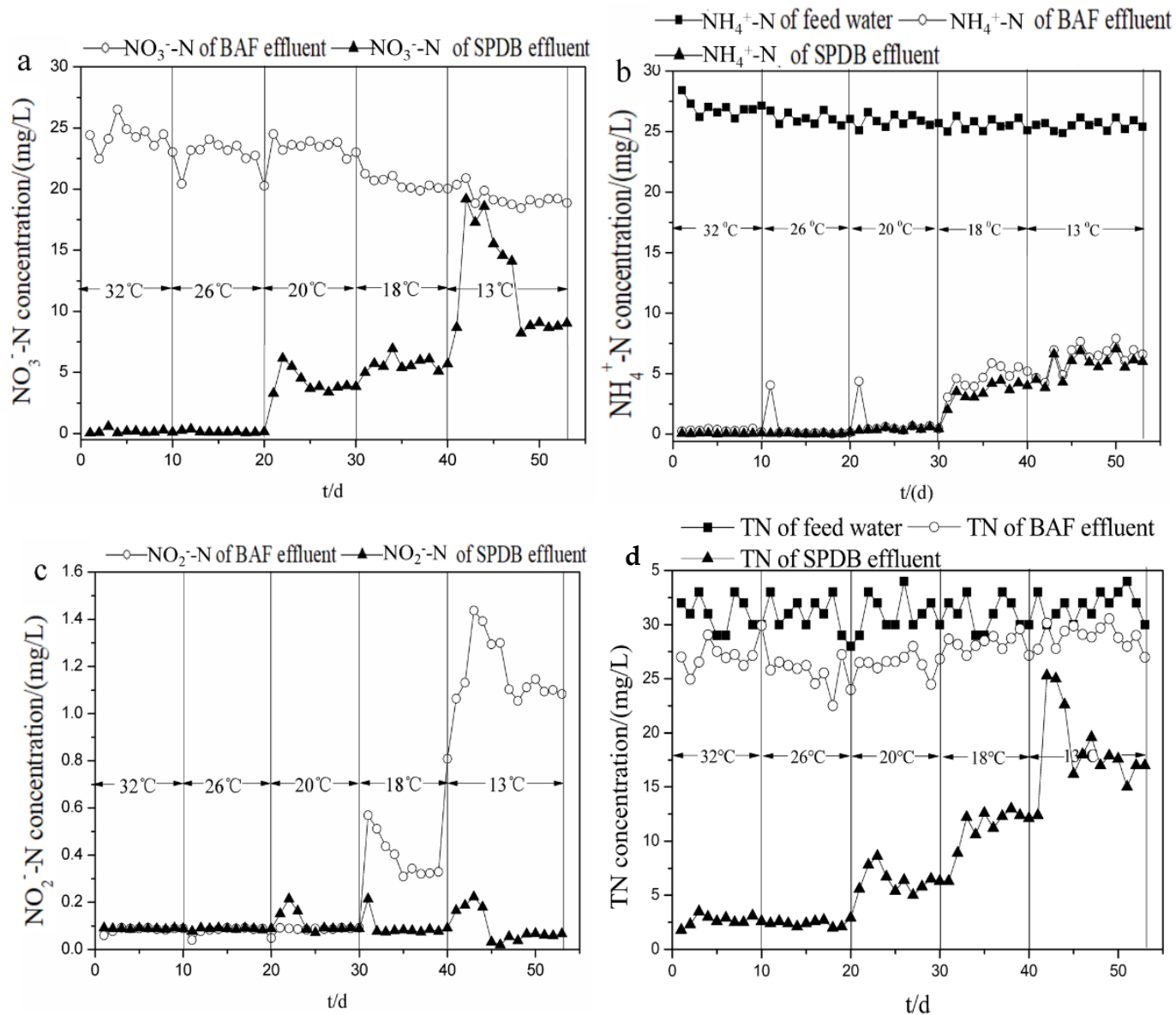

Figure 2. Influence of temperature on effluent (a) nitrate, (b) ammonia, (c) nitrite and (d) TN concentration of biological aeration filters (BAF) and solid-phase denitrification biofilters (SPDB).

\subsection{The Analysis of DGGE Profiles}

Figure 3 a shows the dynamic change process of microbial communities in the BAF at temperatures of $26,20,18$ and $13{ }^{\circ} \mathrm{C}$, respectively. The band numbers of each lane at the temperature $26,20,18$, 13 were $33,13,13$ and 13, respectively. The diversity of microbial communities in BAF decreased dramatically when the temperature decreased from 26 to $20{ }^{\circ} \mathrm{C}$ and then remained stable as the temperature further decreased to $13{ }^{\circ} \mathrm{C}$, indicating that the bacteria abundance in BAF fell sharply when the temperature was less than $20^{\circ} \mathrm{C}$. Similar results were also obtained in the previous researches by Zhu et al. [21].

As can be seen from quantitative analysis diagrams in Figure 3a, DGGE bands 8, 9, 10, 11 and 12 existed in all the four lanes, indicating that the strains corresponding to these bands have strong adaptability and wide ecological amplitude, and thereby can survive under different temperature conditions. The band signal of band 8 decreased gradually, and band 11 changed little, while bands 9, 10 and 12 increased gradually, suggesting that temperature had a certain influence on corresponding strains. DGGE bands 7 and 13 only appear in the last three lanes, and with the decrease of temperature the corresponding strains gradually become the dominant bacteria, which means that these microorganisms have a strong ability to resist low temperature, and have more competitive advantages at low temperature. DGGE bands 1, 2, 3 and 5 only appeared in lane 1, indicating that these strains had harsher environment demand, and were eliminated at low temperature due to the loss of competitive advantage. DGGE band 6 on behalf of strains was the dominant bacteria in lane 1 , but with decreasing temperature this strain gradually disappeared from the lane too. 
Figure $3 \mathrm{~b}$ shows the dynamic change process of microbial communities in the SPDB at temperatures of 26, 20, 18 and $13{ }^{\circ} \mathrm{C}$, respectively. The band numbers of each lane at the temperature 26, 20, 18, 13 were 33, 20, 20 and 19, respectively. In SPDB, the variation trend of microbial diversity with temperature was in consistent with that of $\mathrm{BAF}$, but the decreasing range of microbial diversity in SPDB is lower than that of BAF.

As was shown in the quantitative analysis diagrams of Figure 3b, DGGE bands 2, 3, 6, 10, 11, 12 and 13 existed in all the three lanes, indicating that the strains corresponding to these bands have strong adaptability and wide ecological amplitude, and can survive under different temperature conditions. The band signal of bands 2 and 3 decreased gradually, bands 11 and 13 increased gradually, and band 12 changed little, while bands 6 and 12 increased firstly and then kept invariant. Therefore, it can be inferred that temperature had a certain influence on corresponding strains. DGGE bands 1,4 , and 7 only appeared in lane 1, indicating that these strains had harsher environment demand, and were eliminated at low temperature due to the loss of competitive advantage. The band signals of bands 8 and 9 decreased firstly and then disappeared as temperatures decreased, indicating that the strains represented by these bands can survive only within a certain temperature range, and cannot survive at low temperatures. DGGE band 14 with intensive signals only existed in the third lane, suggesting that the corresponding strains were cold resistant bacteria that can only survive at low temperature.

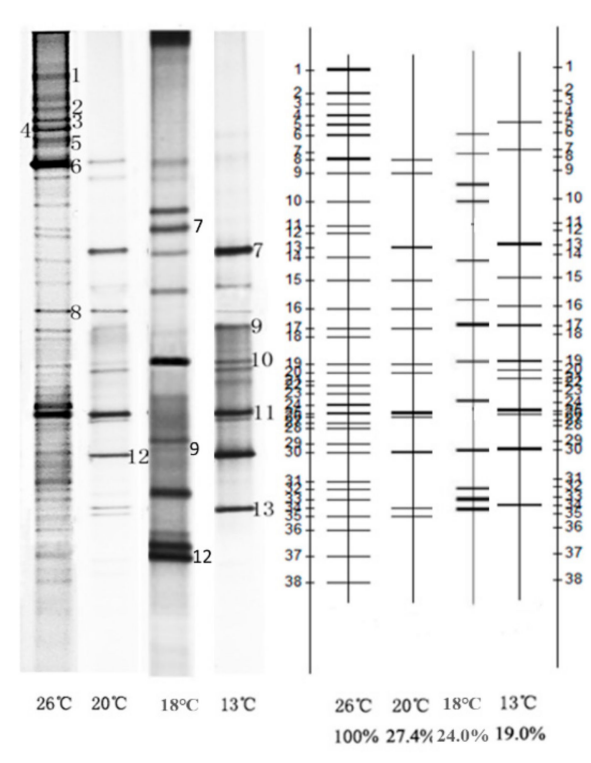

(a)

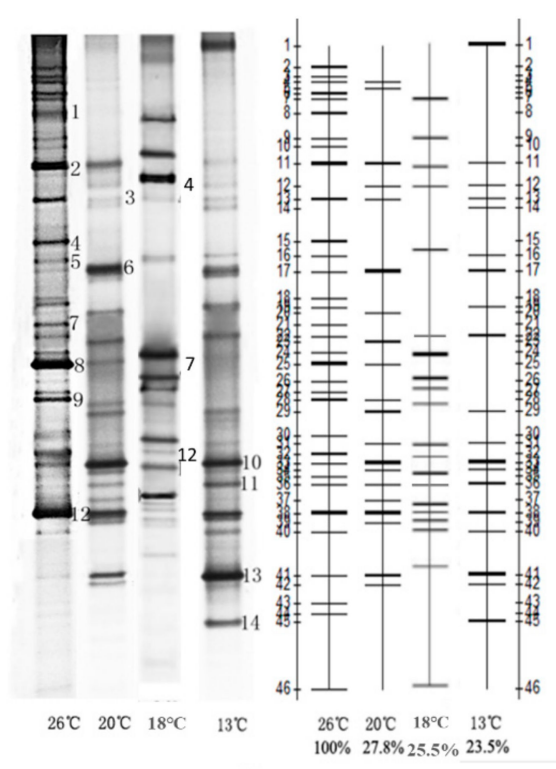

(b)

Figure 3. Comparison of the DGGE patterns and quantitative analysis diagrams of biofilm samples taken from different gas/water ratio conditions: (a) BAF; (b) SPDB.

\subsection{Sequencing and Discussion}

Tables 4 and 5, Figures 4 and 5 shows the analysis results of DGGE gel bands recovery sequence and the phylogenetic tree of the main colonial species in BAF and SPDB, respectively. 
Table 4. The analysis results of DGGE gel bands recovery sequence in BAF.

\begin{tabular}{|c|c|c|c|c|}
\hline \multicolumn{5}{|c|}{ The Analysis Results of DGGE Gel Bands Recovery Sequence } \\
\hline Band Number & Similar Strain & Accession Number & Similarity & Classification \\
\hline Band1 & Labilithrixluteola & NR_126182 & 98 & $\begin{array}{l}\text { Proteobacteria } \\
\text { Labilithrix }\end{array}$ \\
\hline Band2 & uncultured bacterium & КС797661 & 99 & $\begin{array}{c}\text { Bacteria; } \\
\text { environmental } \\
\text { samples }\end{array}$ \\
\hline Band3 & Dechloromonasagitata & KF800710 & 98 & $\begin{array}{l}\text { Proteobacteria } \\
\text { Dechloromonas }\end{array}$ \\
\hline Band4 & Lactococcus sp. R.M17 & HG937722 & 100 & $\begin{array}{l}\text { Firmicutes } \\
\text { Lactococcus }\end{array}$ \\
\hline Band5 & Rubrivivaxgelatinosus & KF911343 & 99 & $\begin{array}{l}\text { Proteobacteria } \\
\text { Rubrivivax }\end{array}$ \\
\hline Band6 & $\begin{array}{c}\text { Gracilibacteria bacterium } \\
\text { oral taxon } 872\end{array}$ & JX294353 & 98 & $\begin{array}{c}\text { Bacteria; } \\
\text { Gracilibacteria }\end{array}$ \\
\hline Band7 & Bosea sp. & AB974256 & 100 & Proteobacteria Bosea \\
\hline Band8 & Nitrosomonas sp. Nm47 & AY123810 & 95 & $\begin{array}{l}\text { Proteobacteria } \\
\text { Nitrosomonas }\end{array}$ \\
\hline Band9 & Acinetobacter sp. & KР636746 & 100 & $\begin{array}{l}\text { Proteobacteria } \\
\text { Acinetobacter }\end{array}$ \\
\hline Band10 & $\begin{array}{l}\text { Acinetobacter } \\
\text { calcoaceticus }\end{array}$ & KR856228 & 100 & $\begin{array}{l}\text { Proteobacteria } \\
\text { Acinetobacter }\end{array}$ \\
\hline Band11 & CandidatusNitrospiradefluvii & NR_074700 & 99 & $\begin{array}{l}\text { Nitrospirae } \\
\text { Nitrospira }\end{array}$ \\
\hline Band12 & Acinetobacter bouvetii & KJ865593 & 100 & $\begin{array}{l}\text { Proteobacteria } \\
\text { Acinetobacter }\end{array}$ \\
\hline Band13 & Bacillus sp. & KT452789 & 100 & Firmicutes Bacillus \\
\hline
\end{tabular}

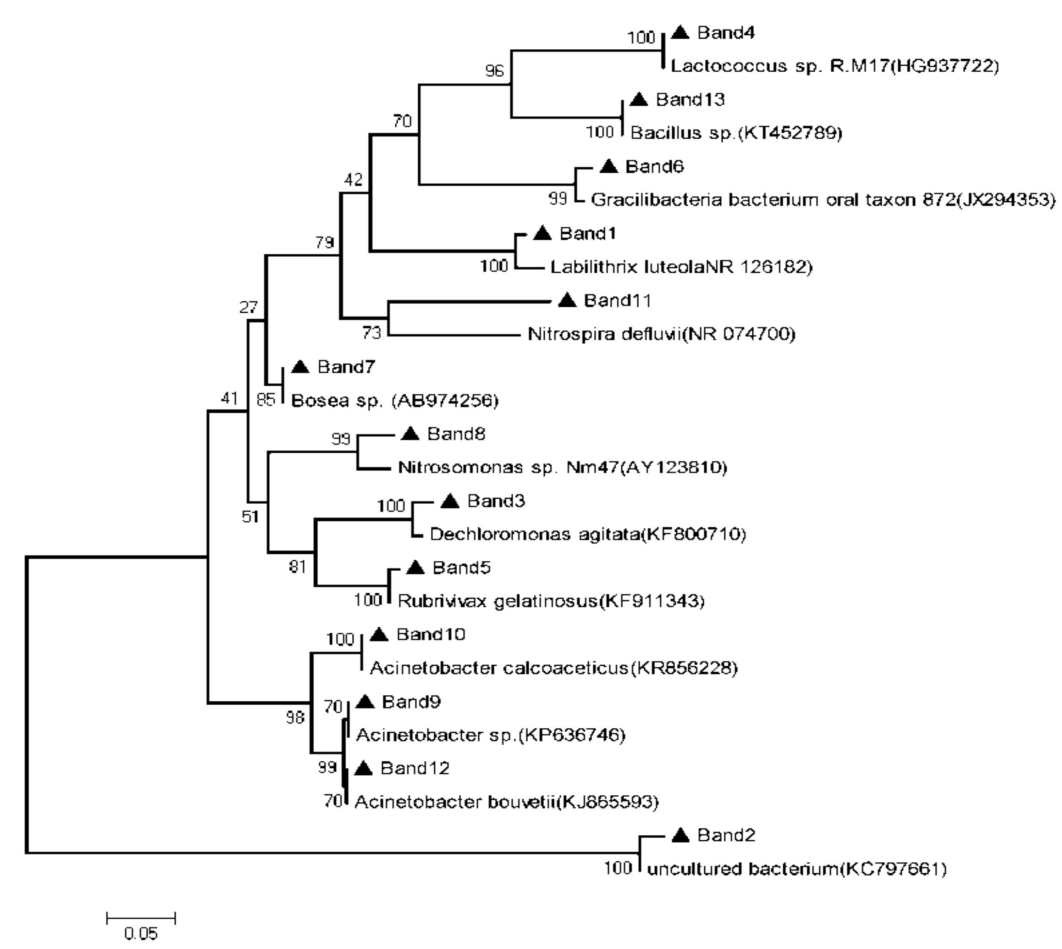

Figure 4. The phylogenetic tree of the main colonial species in BAF. 
Table 5. The analysis results of DGGE gel bands recovery sequence in SPDB.

\begin{tabular}{|c|c|c|c|c|}
\hline \multicolumn{5}{|c|}{ The Analysis Results of DGGE Gel Bands Recovery Sequence } \\
\hline Band Number & Similar Strain & Accession Number & Similarity & Classification \\
\hline Band1 & Dechloromonasagitata & KF800710 & 98 & $\begin{array}{l}\text { Proteobacteria } \\
\text { Dechloromonas }\end{array}$ \\
\hline Band2 & Myxobacterium AT3-03 & AB246770 & 96 & $\begin{array}{l}\text { Proteobacteria } \\
\text { Myxococcales }\end{array}$ \\
\hline Band3 & Pseudomonas sp. & KP711533 & 100 & $\begin{array}{l}\text { Proteobacteria } \\
\text { Pseudomonas }\end{array}$ \\
\hline Band4 & Thaueraaminoaromatica & FJ609688 & 100 & $\begin{array}{l}\text { Proteobacteria } \\
\text { Thauera }\end{array}$ \\
\hline Band5 & uncultured bacterium & FJ229147 & 96 & $\begin{array}{c}\text { Bacteria; } \\
\text { environmental } \\
\text { samples }\end{array}$ \\
\hline Band6 & Bosea sp. & AB974256 & 100 & Proteobacteria Bosea \\
\hline Band7 & Nitrosomonas sp. Nm47 & AY123810 & 95 & $\begin{array}{l}\text { Proteobacteria } \\
\text { Nitrosomonas }\end{array}$ \\
\hline Band8 & Acinetobacter sp. & KР636746 & 100 & $\begin{array}{l}\text { Proteobacteria } \\
\text { Acinetobacter }\end{array}$ \\
\hline Band9 & Comamonasgranuli & NR_114013 & 98 & $\begin{array}{c}\text { Proteobacteria } \\
\text { Comamonas }\end{array}$ \\
\hline Band10 & $\begin{array}{l}\text { Acinetobacter } \\
\text { haemolyticus }\end{array}$ & KT260794 & 100 & $\begin{array}{l}\text { Proteobacteria } \\
\text { Acinetobacter }\end{array}$ \\
\hline Band11 & Acinetobacter sp. & KT361093 & 100 & $\begin{array}{l}\text { Proteobacteria } \\
\text { Acinetobacter }\end{array}$ \\
\hline Band12 & Rubrivivaxgelatinosus & NR_074794 & 99 & $\begin{array}{l}\text { Proteobacteria } \\
\text { Rubrivivax }\end{array}$ \\
\hline Band13 & Bacillus sp. & KT452789 & 100 & Firmicutes Bacillus \\
\hline Band14 & Thiobacillusaquaesulis & LN794608 & 99 & $\begin{array}{l}\text { Proteobacteria } \\
\text { Thiobacillus }\end{array}$ \\
\hline
\end{tabular}

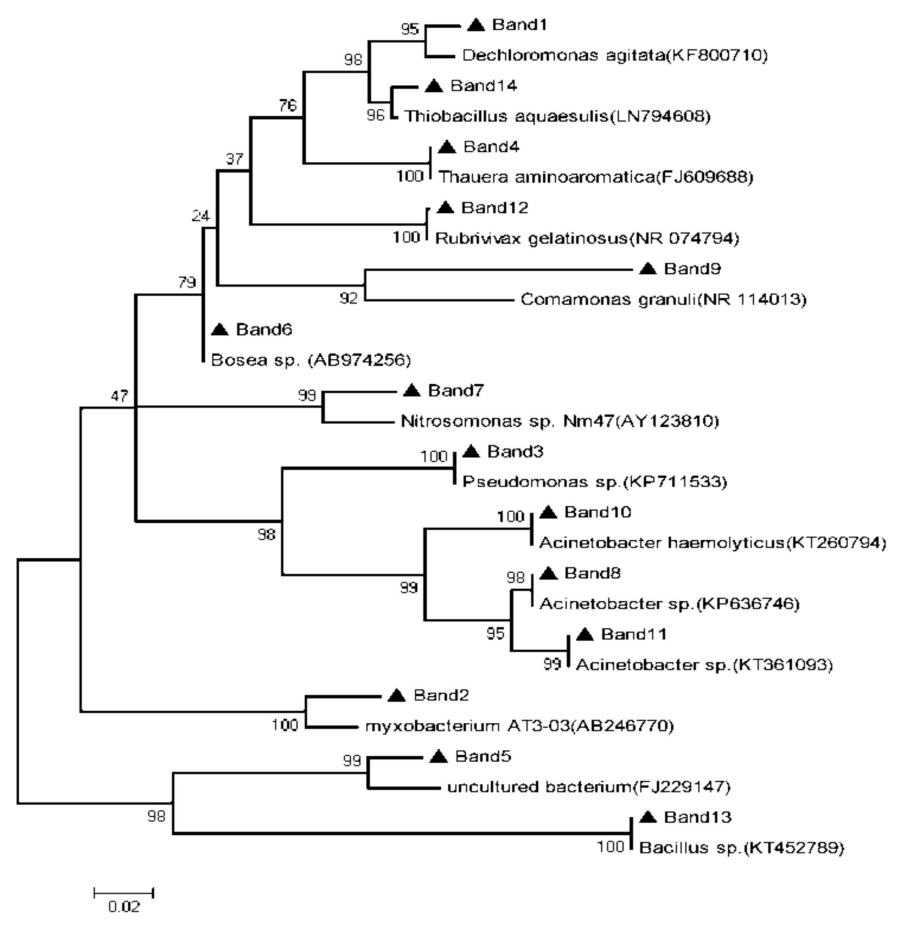

Figure 5. The phylogenetic tree of the main colonial species in SPDB. 
As can be seen from Table 4 and Figure 4, DGGE bands 8 and 11 showed $95 \%$ and $99 \%$ similarity to Nitrosomonas sp. Nm47 and Candidatus Nitrospira defluvii, respectively, which are important ammonia oxidizing bacteria and nitrite oxidizing bacteria found in wastewater biological treatment system [22,23]. When the temperature decreased from 26 to $20^{\circ} \mathrm{C}$, the band signals of bands 8 and 11 changed little, indicating that the reduction of temperature in a certain range would not significantly affect the composition and biomass of nitrifying bacteria. When the temperature further decreased from 20 to $13^{\circ} \mathrm{C}$, however, the brightness of strip 8 declined obviously, while that of strip 11 changed slightly, suggesting that the growth of ammonia oxidizing bacteria was restrained under low temperature conditions, and the biomass of microorganisms therefore decreased, but the growth rate of nitrite oxidizing bacteria in the temperature range of $5-20^{\circ} \mathrm{C}$ was much higher than that of ammonia oxidizing bacteria, so the effect of low temperature on the growth of nitrite oxidizing bacteria was much less than that of ammonia oxidizing bacteria. As can be seen from the nitrification performance of BAF under different temperatures in Figure 3, the ammonia nitrogen and nitrite nitrogen concentration in the effluent of BAF maintained at a low level, while the effluent nitrate concentration remained at a high level when the temperature decreased from 26 to $20^{\circ} \mathrm{C}$. The stability of the biomass and microbial composition of nitrifying bacteria mentioned above might be the main reason for the stable nitrification performance of BAF during the temperature decreasing process. It can also be inferred that the nitrification activity of nitrifying bacteria was not influenced when the temperature decreased from 26 to $20^{\circ} \mathrm{C}$. When the temperature continued to decrease from 20 to $13^{\circ} \mathrm{C}$, the concentration of ammonia nitrogen and nitrite nitrogen in the effluent of BAF increased obviously. Due to the decrease in the biomass of ammonia oxidizing bacteria, the oxidation process of ammonia nitrogen is inhibited to some extent, and therefore ammonia nitrogen in the influent could not be completely oxidized to nitrite. Although the biomass of nitrite oxidizing bacteria changed little, the nitrification activity is affected by lower temperature. Therefore, nitrite produced by ammonia oxidizing bacteria could not be further oxidized to nitrate in time, resulting in the accumulation of nitrite to some extent. DGGE bands 9, 10 and 13 displayed 100\% similarity with Acinetobacter sp., Acinetobacter calcoaceticus and Bacillus sp., respectively, all of which are heterotrophic nitrifying bacteria. Acinetobacter sp. comes mainly from the ABS wastewater treatment system, which can oxidize ammonia nitrogen to nitrite and nitrate [24]. Bacillus sp. is a heterotrophic nitrification-aerobic denitrifying bacteria isolated from MBR system. It can not only oxidize ammonia nitrogen to nitrite, but also reduce nitrite to nitrogen [25]. Acinetobacter calcoaceticus can convert ammonia to nitrate, but could not reduce nitrate to nitrite or nitrogen gas under aerobic conditions [26]. The biomass of all these microorganisms increased gradually with the decrease of temperature, and gradually developed into a dominant flora, indicating that these microorganisms have a strong ability to resist low temperature, and have more competitive advantages at low temperature. Previous research proved that Acinetobacter sp., Acinetobacter calcoaceticus and Bacillus sp., all showed capacity of heterotrophic nitrification under very low temperature due to the regulation of metabolic pathway, synthesis of protein and protein refolding [27-29], which further confirmed the above hypothesis. Because of the presence of these cold resistant heterotrophic nitrifying bacteria, BAF could maintain strong nitrification ability at low temperature.

As can be seen from Table 5 and Figure 5, DGGE bands 1, 2, 3, 4, 9 and 12 show 98\%, 96\%, $100 \%, 100 \%, 98 \%$ and $100 \%$ similarity to Dechloromonas agitata, Myxobacterium AT3-03, Pseudomonas sp, Thauera aminoaromatica, Comamonas granuli and Rubrivivax gelatinosus [30-35], respectively, and all of these bacterial strain exhibited denitrification ability. DGGE bands 1 and 4 , on behalf of the denitrifying bacteria Dechloromonas agitate and Thauer aaminoaromatica, were only found in Lane 1, which indicates that these two kinds of microorganisms can survive only in relatively high temperature conditions. DGGE bands 2 and 3 on behalf of Myxobacterium AT3-03 and Pseudomonas sp. can degrade the polymers into small molecules to provide the necessary organic carbon for denitrification $[31,36]$. With the decrease of temperature, the brightness of the strip 2 and 3 in each lane also decreased (Figure 3), indicating that the biomass of these two kinds of microorganisms declined with the decrease of temperature, but the microbial composition did not change, making it possible for the two kinds 
of microorganisms to degrade polymers to provide the necessary organic carbon for denitrification under different temperature conditions. Yao et al. [37] also found that Pseudomonas sp. played a major role in denitrification under low temperature. Comamonas granuli (band 8 ) was a common denitrifying bacterium in solid-phase denitrification process [38]. The brightness of strip 8 decreased with the temperature firstly and then disappeared from the lane, indicating that Comamonas granuli had poor ability on cold tolerance, and therefore can only survive in a certain temperature range. DGGE band 12 , on behalf of Rubrivivax gelatinosus, represented the predominant strain, the biomass of which changed very little during the temperature changing process, suggesting that the microorganism has stronger resistance to low temperature. As can be seen from Figure 3, when the temperature decreased from 26 to $20^{\circ} \mathrm{C}$, no obvious change was observed in the influent nitrate concentration of SPDB, but the effluent nitrate concentration increased significantly. According to the change of microorganism biomass and microbial composition with the temperature mentioned above, the disappearance of some denitrifying bacteria (band 1 and 4 ) and biomass decreasing of polymers degrading denitrifying bacteria (band 2 and 3) might be the main course for the deterioration of denitrification. When the temperature continued to decrease from 20 to $13{ }^{\circ} \mathrm{C}$, the nitrate concentration in the effluent of SPDB increased further, indicating that the denitrification performance continued to deteriorate. Although low temperature resistant aerobic denitrifying bacteria Acinetobacter sp. (band 11) and Bacillus sp. (band 13) [37,39] gradually developed into dominant bacteria with decreasing temperature, and the negative effect of denitrifying bacteria Comamonas Granuli (band 8) disappeared from the strip on denitrification was therefore compensated, the further biomass decrease of polymers degrading denitrifying bacteria Myxobacterium AT3-03 significantly reduced the organic carbon release. Due to the insufficient electronic donors supply, denitrification in SPDB was greatly inhibited.

\subsection{Characterization of Biofilm Carriers under Different Temperature by ESEM}

To track the biofilm development on the clay ceramsite and PCL carriers and elucidate the effect of temperature on biofilm structure, ESEM observations were conducted under the temperature of $26^{\circ} \mathrm{C}$, $20^{\circ} \mathrm{C}, 18^{\circ} \mathrm{C}$ and $13^{\circ} \mathrm{C}$. Figure 6 provides an impression of the surface structure and biofilm coverage on the outer surface of the clay ceramsite and PCL carriers during the temperature changing. As seen in Figure 6, with the decrease of temperature, the biomass attached to the surface of clay ceramsite and PCL carriers decreased gradually. The biofilm attached was thick and dense when the temperature was $26^{\circ} \mathrm{C}$, but when the temperature decreased from $26^{\circ} \mathrm{C}$ to $13^{\circ} \mathrm{C}$, the biofilm became thinner and sparse, leading to the part-exposure of the bare carrier surface. Temperature had little effect on the morphology of microorganisms on the surface of clay ceramsite (Figure 6a-d), but had significant effect on that of the PCL carriers. From Figure $6 \mathrm{e}-\mathrm{g}$, it can be seen that spheroidal bacteria and rod-shaped bacteria are the main microorganisms on the surface of PCL carriers when the temperature was $26^{\circ} \mathrm{C}$, but the number of spheroidal bacteria decreased with the decreasing temperature. When the temperature was $18^{\circ} \mathrm{C}$, rod-shaped bacteria was the main microorganism on the surface of PCL carriers, and almost no spheroidal bacteria existed. This was consistent with the previous DGGE analysis results which showed that Acinetobacter sp. and Bacillus sp., two rod-shaded bacteria, gradually developed into dominant bacteria when the temperature decreased to $13^{\circ} \mathrm{C}$. 

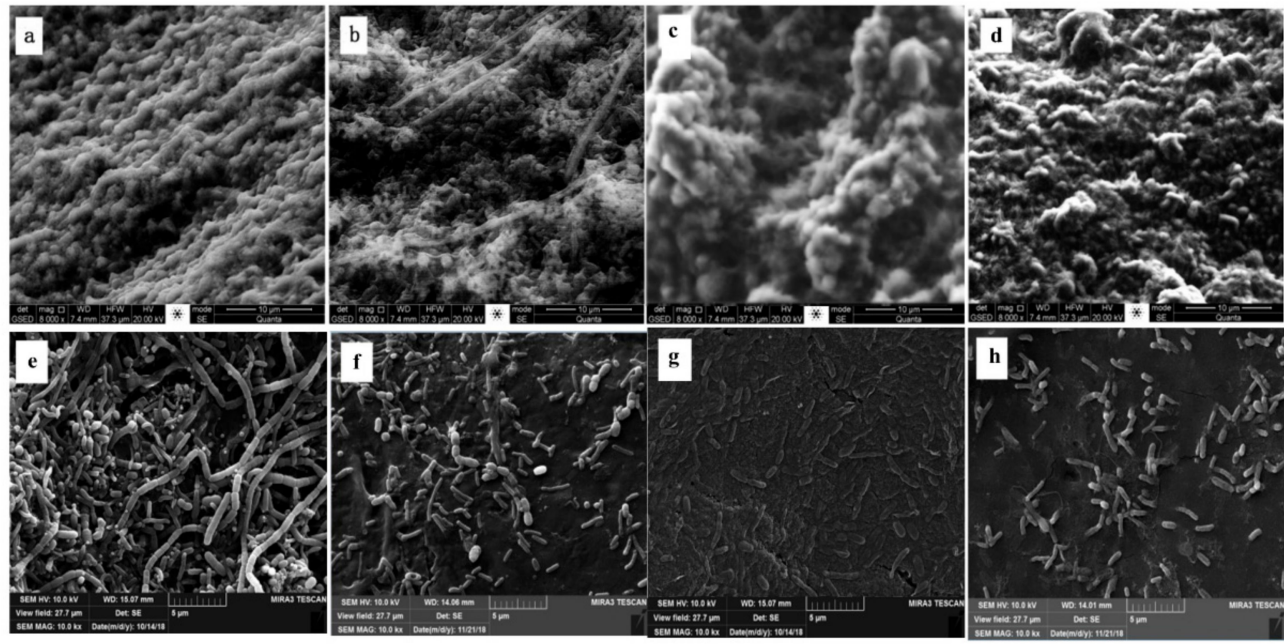

Figure 6. Environmental scanning electron microscope (ESEM) observations of surface of clay ceramsite with biofilm under (a) $26^{\circ} \mathrm{C}$, (b) $20^{\circ} \mathrm{C}$, (c) $18^{\circ} \mathrm{C}$, (d) $13^{\circ} \mathrm{C}$ and surface of PCL carrier with biofilm under (e) $26{ }^{\circ} \mathrm{C}$, (f) $20^{\circ} \mathrm{C},\left(\right.$ g) $18{ }^{\circ} \mathrm{C}$, (h) $13{ }^{\circ} \mathrm{C}$.

\section{Conclusions}

a. In the CS-BAF-SPDB combined process, to realize favorable nitrifying and denitrifying performance simultaneously in the BAF-SPDB unit, the temperature should be controlled above $18{ }^{\circ} \mathrm{C}$ when the influent $\mathrm{C} / \mathrm{N}$ ratio and gas/water ratio of $\mathrm{BAF}$ is $3: 1$ and $4: 1$, respectively, and HRT of BAF and SPDB is $3.5 \mathrm{~h}$ and $1.5 \mathrm{~h}$, respectively. The $\mathrm{NH}_{4}{ }^{+}-\mathrm{N}$ and TN removal efficiency of BAF-SPDB unit can reach more than $96.2 \%$ and $81.2 \%$ when the temperature is above $18^{\circ} \mathrm{C}$.

b. In addition, the influence of the macro operation parameters on the performance of the BAF and SPDB has a direct relationship with the dynamic changes of the micro microbial community. The influence of temperature on nitrification performance in BAF is mainly embodied in the change of composition, amount and activity of ammonia oxidizing bacteria Candidatus Nitrospira defluvii and nitrite oxidizing bacteria Nitrosomonas sp. Denitrification performance of Nm47 in SPDB is mainly embodied in the change of composition and amount of solid carbon substrate degrading denitrifying bacteria Pseudomonas sp., Myxobacterium AT3-03 and heterotrophic denitrifying bacteria Dechloromonas agitate, Thauera aminoaromatica, Comamonas granuli and Rubrivivax gelatinosus. Meanwhile, the change of microbial community structure of heterotrophic nitrification and aerobic denitrification with operation conditions also plays a very important role in ensuring the stable nitrification and denitrification under low temperature.

Author Contributions: Q.Z., and L.Z. conceived and designed the experiments. X.C., and W.L. did laboratory experiments. H.W., and X.L. analyzed the data. W.C., and J.T. did modelling. Q.Z. wrote the paper.

Funding: This research was funded by the National Natural Science Foundation of China (NO.51908099), Chongqing Research Program of Special Innovation Fund for Public Science and Technology, China (NO. cstc2018jscx-msybX0134) and technological Innovation and Application Demonstration of Chongqing, China (NO. cstc2018jscx-mszdX0005).

Acknowledgments: Thanks for the help from the National Natural Science Foundation of China, Chongqing Research Program of Special Innovation Fund for Public Science and Technology, China and technological Innovation and Application Demonstration of Chongqing, China.

Conflicts of Interest: The authors declare that there is no conflicts of interest. 


\section{References}

1. Sun, S.P.; Nàcher, C.P.; Merkey, B.; Zhou, Q.; Xia, S.Q.; Yang, D.H.; Sun, J.H.; Smets, B.F. Effective biological nitrogen removal treatment processes for domestic wastewaters with low $\mathrm{C} / \mathrm{N}$ ratios: A review. Environ. Eng. Sci. 2010, 27, 111-126. [CrossRef]

2. Gooddy, D.C.; Lapworth, D.J.; Bennett, S.A.; Heaton, T.H.E.; Williams, P.J.; Surridge, B.W.J. A multi-stable isotope framework to understand eutrophication in aquatic ecosystems. Water Res. 2016, 88, $623-633$. [CrossRef] [PubMed]

3. Hao, W.; Miao, B.; Liu, P.P.; Huang, X.; Liang, P. Potential regulation accelerates element sulfur metabolism in sulfur autotrophic denitrification. J. Clean. Prod. 2019, 228, 94-100. [CrossRef]

4. Qiu, Y.Y.; Zhang, L.; Mu, X.T.; Li, G.B.; Guan, X.Q.; Hong, J.Y.; Jiang, F. Overlooked pathways of denitrification in a sulfur-based denitrification system with organic supplementation. Water Res. 2019, 115084. [CrossRef]

5. Wang, Q.B.; Chen, Q.W.; Chen, J. Optimizing external carbon source addition in domestics wastewater treatment based on online sensoring data and a numerical model. Water Sci. Technol. 2017, 75, 2716-2725. [CrossRef]

6. Ying, C.; Zhen, P.Y.; Min, L.; Ping, G.Y.; Shu, Y.W. Non-filamentous activated sludge bulking in SBR treating the domestic wastewater. Acta Scien. Circum. 2005, 25, 105-108.

7. Rother, E.; Cornel, P. Potentials and limits of a pre-denitrification/nitrification biofilter configuration for advanced municipal wastewater treatment. Water Sci. Technol. 2007, 55, 115-123. [CrossRef]

8. Wang, J.L. Denitrification using PBS as carbon source and biofilm support in a packed-bed bioreactor. Environ. Sci. Pollut. Res. Int. 2013, 20, 333-339.

9. Walters, E.; Hille, A.; He, M.; Ochmann, C.; Horn, H. Simultaneous nitrification/denitrification in a biofilm airlift suspension (BAS) reactor with biodegradable carrier material. Water Res. 2009, 43, 4461-4468. [CrossRef]

10. Hille, A.; He, M.; Ochmann, C.; Neu, T.R.; Horn, H. Application of two component biodegradable carriers in a particle-fixed biofilm airlift suspension reactor: Development and structure of biofilms. Bioprocess Biosyst. Eng. 2009, 32, 31-39. [CrossRef]

11. Ginige, M.P.; Wang, J.L. Comparison of polyurethane foam and biodegradable polymer as carriers in moving bed biofilm reactor for treating wastewater with a low $\mathrm{C} / \mathrm{N}$ ratio. Chemosphere 2011, 83, 63-68.

12. Shen, Z.Q.; Zhou, Y.X.; Liu, J.; Xiao, Y.; Cao, R.; Wu, F.P. Enhanced removal of nitrate using starch/PCL blends as solid carbon source in a constructed wetland. Bioresour. Technol. 2015, 175, 239-244. [CrossRef] [PubMed]

13. Rodrigues, A.L.; Machado, A.V.; Nóbrega, J.M.; Albuquerque, A. A poly- $\varepsilon$-caprolactone based biofilm carrier for nitrate removal from water. Int. J. Environ. Sci. Technol. 2014, 11, 263-268. [CrossRef]

14. Llies, P.; Mavinic, D.S. The effect of decreased ambient temperature on the biological nitrification and denitrification of a high ammonia landfill leachate. Water Res. 2001, 35, 2065-2072.

15. Ha, J.H.; Ong, S.K.; Surampalli, R.; Song, J.H. Temperature effects on nitrification in polishing biological aerated filters (BAFs). Environ. Technol. 2010, 31, 671-680. [CrossRef]

16. Zhang, Q.; Ji, F.Y.; Fu, X.F.; Chen, Q.K. Effects of Gas/Water Ratio on the Characteristics of Nitrogen Removal and the Microbial Community in Post Solid-Phase Denitrification Biofilter Process. Huan Jing Ke Xue= Huanjing Kexue 2018, 39, 3297-3305.

17. He, S.B.; Xue, G.; Kong, H.N. The performance of BAF using natural zeolite as filter media under conditions of low temperature and ammonium shock load. J. Hazard. Mater. 2007, 143, 291-295. [CrossRef]

18. Antoniou, P.; Hamilton, J.; Koopman, B.; Jain, R.; Holloway, B.; Lyberatos, G. Effect of temperature and pH on the effective maximum specific growth rate of nitrifying bacteria. Water Res. 1990, 24, 97-101. [CrossRef]

19. Wang, X.M.; Wang, J.L. Denitrification of nitrate-contaminated groundwater using biodegradable snack ware as carbon source under low-temperature condition. Int. J. Environ. Sci. Technol. 2012, 9, 113-118. [CrossRef]

20. Rusmana, I. Effects of temperature on denitrifying growth and nitrate reduction end products of comamonas testosteroni isolated from estuarine sediment. Microbiol. Indones. 2007, 1, 43-47. [CrossRef]

21. Zhu, S.M.; Chen, S.L. The impact of temperature on nitrification rate in fixed film biofilters. Aquac. Eng. 2002, 26, 221-237. [CrossRef]

22. Okabe, S.; Satoh, H.; Watanabe, Y. In situ analysis of nitrifying biofilms as determined by in situ hybridization and the use of microelectrodes. Appl. Environ. Microbiol. 1999, 65, 3182-3191. [PubMed] 
23. Kostan, J.; Sjöblom, B.; Maixner, F.; Mlynek, G.; Furtmüller, P.G.; Obinger, C. Structural and functional characterisation of the chlorite dismutase from the nitrite-oxidizing bacterium "candidatus nitrospira defluvii": Identification of a catalytically important amino acid residue. J. Struct. Biol. 2010, 172, 0-342. [CrossRef] [PubMed]

24. Su, J.F.; Zhang, K.; Huang, T.L.; Wen, G.; Guo, L.; Yang, S.F. Heterotrophic nitrification and aerobic denitrification at low nutrient conditions by a newly isolated bacterium, Acinetobacter sp. SYF26. Microbiology 2015, 161, 829-837. [CrossRef] [PubMed]

25. Lin, Y.; Kong, H.N.; Wu, D.Y.; Li, C.J.; Wang, R.Y.; Tanaka, S. Physiological and molecular biological characteristics of heterotrophic ammonia oxidation by Bacillus sp. LY. World J. Microbiol. Biotechnol. 2010, 26, 1605-1612. [CrossRef]

26. Zhao, B.; He, Y.L.; Joseph, H.; Zhang, X.F. Heterotrophic nitrogen removal by a newly isolated Acinetobacter calcoacetiticusi HNR. Bioresour. Technol. 2010, 101, 5194-5200. [CrossRef]

27. Qin, W.; Li, W.G.; Huang, X.F.; Zhang, D.Y.; Song, Y. A proteomic analysis of heterotrophic nitrifying bacterium Acinetobacter sp. HITLi 7T adaptation to low temperature using two-dimensional difference gel electrophoresis approach. Int. Biodeterior. Biodegrad. 2016, 113, 113-119. [CrossRef]

28. Huang, X.F.; Li, W.G.; Zhang, D.Y.; Qin, W. Ammonium removal by a novel oligotrophic Acinetobacter sp. Y16 capable of heterotrophic nitrification-aerobic denitrification at low temperature. Bioresour. Technol. 2013, 146, 44-50. [CrossRef]

29. Kawahara, H. The structures and functions of ice crystal-controlling proteins from bacteria. J. Biosci. Bioeng. 2002, 94, 492-496. [CrossRef]

30. Achenbach, L.A.; Michaelidou, U.; Bruce, R.A.; Fryman, J.; Coates, J.D. Dechloromonas agitata gen. nov. sp. nov., and Dechlorosoma suillum gen. nov., sp. nov. two novel environmentally dominant (per)chlorate-reducing bacteria and their phylogenetic position. Int. J. Syst. Evol. Microbiol. 2001, 51, 527-533. [CrossRef]

31. Manucharova, N.A.; Dobrovol'Skaia, T.G.; Stepanov, A.L. Taxonomy of denitrifying bacteria in soddy podzolic soil. Mikrobiologiia 2000, 69, 286. [PubMed]

32. Chen, C.; Ho, K.L.; Liu, F.C.; Ho, M.; Wang, A.; Ren, N. Autotrophic and heterotrophic denitrification by a newly isolated strain Pseudomonas sp. C27. Bioresour. Technol. 2013, 145, 351-356. [CrossRef] [PubMed]

33. Ginige, M.P.; Keller, J.; Blackall, L.L. Investigation of an acetate-fed denitrifying microbial community by stable isotope probing, full-cycle rRNA analysis, and fluorescent in situ hybridization-microautoradiography. Appl. Environ. Microbiol. 2005, 71, 8683-8691. [CrossRef] [PubMed]

34. Kim, K.H.; Ten, L.N.; Liu, Q.M.; Im, W.T.; Lee, S.T. Comamonas granuli sp. nov. isolated from granules used in a wastewater treatment plant. J. Microbiol. 2008, 46, 390-395. [CrossRef]

35. Ichikawa, N.; Hanada, S.; Yamazaki, S.; Shimizu, T.; Fujita, N.; Sekine, M. Complete genome sequence of phototrophic betaproteobacterium Rubrivivax gelatinosus IL144. J. Bacteriol. 2012, 194, 3541-3542.

36. Li, S.; Liu, L.; Garreau, H.; Vert, M. Lipase-catalyzed biodegradation of poly( $\varepsilon$-caprolactone) blended with various polylactide-based polymers. Biomacromolecules 2003, 4, 372-377. [CrossRef]

37. Yao, S.; Ni, J.R.; Ma, T.; Li, C. Heterotrophic nitrification and aerobic denitrification at low temperature by a newly isolated bacterium, Acinetobacter sp. HA2. Bioresour. Technol. 2013, 139, 80-86. [CrossRef]

38. Wu, W.Z.; Yang, L.H.; Wang, J.L. Denitrification performance and microbial diversity in a packed-bed bioreactor using PCL as carbon source and biofilm carrier. Appl. Microbiol. Biotechnol. 2013, 97, 2725-2733. [CrossRef]

39. Wang, H.Y.; Zou, Z.C.; Chen, D.; Yang, K. Effects of temperature on aerobic denitrification in a bio-ceramsite reactor. Energy Sources Part A 2016, 38, 3236-3241. [CrossRef]

(C) 2019 by the authors. Licensee MDPI, Basel, Switzerland. This article is an open access article distributed under the terms and conditions of the Creative Commons Attribution (CC BY) license (http://creativecommons.org/licenses/by/4.0/). 